821.163.41-32.09 Булатовић, Миодраг https://doi.org/10.18485/msc.2018.47.2.ch28

Лидија Р. ТОМИЋ*

Универзитет Црне Горе, Подгорица Филолошки факултет, Никшић
Оригинални научни рад

Примљен: 20. 11. 2017.

Прихваћен: 27. 12. 2017.

\title{
ПОСТУПЦИ КАРНЕВАЛИЗАЦИЈЕ У ПРИПОВЈЕДНОЈ ПРОЗИ МИОДРАГА БУЛАТОВИЋА
}

\begin{abstract}
Поступци карневализације у приповијеткама Миодрага Булатовића огледају се у обликовној равни слике свијета. С обзиром на то да дионизијски принцип раздешене стварности у прози овог писца уноси мноштво деформних облика зла и добра, карневализација као поступак омогућава да мотиве страсти и порока читамо у амбивалентној стварности ликова који носе идеју изгубљене хармоније постојања.

Кључне ријечи: карневализација, пародија, снижавање, деканонизација, девастација, смјеховни принцип, апсурд, гротеска, фантастика.
\end{abstract}

Књижевно дјело Миодрага Булатовића опредјељује тему карневализације начином обликовања слике свијета. У српску књижевност Булатовић је ушао књигом приповиједака Баволи долазе (1955) и особинама хладне гротеске, с амиметичким и фикционалним начином приповиједања урбаног живота. Другом књигом приповиједака, под називом Вук $и$ звоно: повести о огњу, заточеницима и још неким људима (1958), Булатовић приповиједа тему рата формом „осјећајно ангажиране гротеске”, с елементима гротескне деструкције ратних тема, које ће „хумористички”, и сатирично, ескалирати у романима о рату (Херој на магариу) и миру (Рат је био бољи). У трећој књизи, роману Црвени петао лети према небу (1959), карневализација се огледа у епско-лирском контрапункту патријархалне традиције и десакрализоване стварности мотива љубави, насиља и патње.

Миодраг Булатовић је, у оквиру прве фазе стваралаштва, до 1959. године, када је објављен роман Црвени петао лети према небу, жанровски објединио приповједну структуру вијенца приповиједака, специфичну по парцелацијама дјелова и обједињености цјелине приповиједака. Прва Булатовићева књига донијела је митски присутан, а поетски искошен простор

*1idija.tomicpg@gmail.com 
егзистенције. Посувраћена стања јунака и помјерени облици људске недовољности и несреће, исказују тему пролазности и узалудности. Булатовићев приповједач открива амбивалентна стања заноса и патње. С обзиром на то да полази од тамних сјећања на дјетињство, с искуством страха и страдања, тема људске угрожености мотивисана је карневализацијом људског пораза која се тиче десакрализације ликова који опсесивно желе да „izađu iz kruga” и постану „vladari, kraljevi, carevi, imperatori i diktatori” (Булатовић 1989a: 85). Уобразиље и морбидне егзалтације учиниле су ликове марионетама људске несреће. С поетичким одредиштима „punovrednog ja” (Бахтин 1967: 113), Булатовићеви јунаци су „мученици”, ,јадници”, „скитнице”, „инсекти”, „љубавници”, с бизарним тежњама за испуњењем. Логика постојања у приповијеткама „Излаз из круга”, „Прича о срећи и несрећи”, „Инсекти”, „Љубавници”, „Тиранија”, „Заустави се, Дунаве”, и насловима, фабулизује помјерени статус ликова, иманентан односу „говорне представе” и говорне емоције” трагикомичних јунака (Ејхенбаум 1970: 246). Ликови „vladaju sobom kao najobičnijim predmetom" (Булатовић 1989a: 143), што у гротесци зла карневализује Булатовићеву „игру с апсурдом”. У њој се исказује тјелесна и духовна отуђеност, оспољена дескрипцијом „пијаница”, „слободних мислилаца”, „подземних генија”, „шизофреника”, „људи од мрака”, „од пене и сенке”, „неботичника”, ликова „с темељима од људских патњи и глине”, „дремовних телеса”. Карневал порока и гријеха, до апокалиптичних самоуништења, обједињен је настојањима јунака да превазиђу зло постојања. Она се одвијају у „тамном вилајету” људске судбине, у свијету социјално и друштвено маргинализованог свијета. Песимистичне и болне исповијести јунака, немотивисане реакције и дијалози, тешко су схватљиви у некарневалском поретку постојања. У карневалском, и из доминације хаоса, казивања ликова усмјерена су ка вишем степену испуњења. Без логичког реда и поретка, емоционално наглашен ритам самоосјећања и фасцинација конституише надреална стања угрожене егзистенције. Гротеска и пародија чулних и физичких сензација говори о изостанаку реалистичке мотивације - осим у два мотива - Ивановом самоубиству и убиству сликара Милана, у причи „Тиранија". Карневализација посувраћености и заробљености агоналним трагањима за смислом поистовјећена је с приповиједањем патетичних и параноичних илузија да је могуће надвисити зло и досегнути добро. Карневалски паноптикум „озбиљно-смешног” даје референцијалну стварност „ђавола” и „демона” помјереног свијета. Њу није изградила реалистичка мотивација приповиједања, већ карневализација пролазности и ништавности којим се Булатовић катарзично „брани” од недовољности постојања и смрти. На тај начин, у духу карневалских прекорачења и многострукости, истина текста је истина једне тежње да се умјетничким средствима активира мисао о „малом човјеку”, оном који књижевно живи у халуцинантним, сомнабулним, хистеричним и другим самоодређењима. Њима Булатовић показује демонску страну људске природе, на рубу хумане егзистенције.

С обзиром на то да књижевна критика није благонаклоно реаговала на појаву књиге Ђаволи долазе, генеза приповиједака ишла је ка другој књи- 
зи, ка повијестима, које настављају карневализацију помјерених ситуација и стања јунака. У теми завичаја развија се тема рата и слика ликова у метафорама ватре и свеопштег пламена. Тема човјекове угрожености, овдје се, у књизи Вук и звоно: повијести о огњу, заточеницима и још неким људима, трансформисала симболима зле и добре ватре у тродимензионалном простору завичаја - друма, тамнице (болнице) и круга страдања и искушења, „таворења и борења".

Поступак карневализације у Булатовићевој приповједној прози огледа се у дијаболичној инверзији епских тема рата и гротескним спојевима тема зла и добра. Књигом приповиједака Баволи долазе Булатовић је објавио јуродиви свијет помјерене стварности, а књигом Вук и звоно, поетску деканонизацију тема рата и револуције. Књигом Црвени петао лети према небу, Булатовићев декомпоновани свијет бића наћи ће се у трагикомичној реалности пада и људског пораза.

Дионизијска распрострањеност људског хаоса, апокалиптичних страсти и порока, трагикомичних снижавања етике, културе и традиције, учинила је да се Булатовићев свијет урбаног и руралног простора налази у карневалској структури човјековог пада. Она садржи амбивалентност, парадоксе и апсурд помјереног свијета, с интензитетом поетске истине о стварности „малог човјека”.

Поступак карневализације креће од језика немира, озарења и иреалистички мотивисаних реакција ликова, њихових покрета и тежњи. Булатовићев приповједач и ликови граде тему посувраћене егзистенције. Она захвата све слојеве наративног свијета, од сижејне организације текста до измијењеног поретка стварности. Озбиљност тема страдања и патње пародијски и иронијски варира карневалске мезалијансе, превласти ниског над узвишеним, порока над врлином. Тим начином, порок заузима простор врлине, баналност простор узвишених тежњи. Узрочно-последични след ствари и појава замијењен је деформном реалношћу људске несреће, са идејом њеног превладавања управо приповиједањем ништавног поретка људске пролазности. Зло постојања открива тамне особине бића, с одуховљеним добром новог облика постојања.

У Булатовићевим књигама Баволи долазе, Вук и звоно, као и у књизи Црвени петао лети према небу, говоримо о карневализацији „страног и страшног” у теми егзистенције и „историјског поретка” (Кајзер 1995: 72). Карневалско осјећање свијета подразумијева „,suočavanje likova najrazličitijih socijalnih i drugih odrednica na jednom malom i uskom prostoru, uz katastrofalnu brzinu zbivanja”, уз предуслов да се сагледа „природа људске празничности” (Бахтин 1978: 16). Другим ријечима, слободе ослобађања као пуноће живота. Код Булатовића, у односу на одреднице празничности, тематизује се бизарно и ниско, човјекова недовољност и осуђеност на патњу. Интензитет тих облика, у духу карневалског обнављања, сасвим гротескно, враћа мисао на лијепо, на изгубљену хармонију постојања. Трагикомична реалност Булатовићевих антијунака поетски декомпонује тему људске несреће, али је и испољава идејом о спасењу. Укидање „svih hijerarhijskih odnosa” (Исто: 17) говори о томе да Булатовићеви јунаци живе ритам страсти и инстинката, без препрека 
„staleškog, imovinskog, službenog, porodičnog i starosnog položaja” (Исто: 17). Тренуци изгубљености, меланхолије песимизма оспољавају искидана, немотивисана и инстинктивна оглашавања недовољности. Говор јунака у складу је с енергијом промашености и заумних тежњи, случајних помисли и коментара. Приповиједање и само постаје поетски трансформативно у гротескној напоредности трагичног и комичног, у њиховој гротескној деформности. На тај начин, Булатовић остварује „најгласнији и најлуциднији отпор сваком рационализму и свакој систематичности мишљења” (Кајзер 1995: 73).

Булатовићев надреални свијет модернистички је заснован на „игри судбине", на негацији њених облика. Све је подложно деконструкцији и отуда бесконачни облик недовољности, због којих се, катарзично, враћа мисао о изгубљеном добру. Њему Булатовићеви јунаци теже као изласку из судбине смрти и нестајања.

Ауторова посвећеност ,rastvaranju oblika u bezobličnom” (Тамарин 1962: 33), учинила је да се приповиједање ликова умножава особинама грешника и праведника, једном ријечју, „божјих људи”, с трагичном кривицом постојања. Пародија, иронија и бурлеска људске цјеловитости говоре о људској пролазности. Цитат из Књиге о Јову, у књизи Баволи долазе („Nije li čovjek na vojsci na zemlji? A dani njegovi nijesu li kao dani nadničarski?), дијалогизује одређеност човјекове судбине на земљи и поетски текст који се, поетском десакрализацијом постојања, сасвим метафорично, доживљава и као „излаз из круга".

„Obredno-predstavljačka forma” (Бахтин 1978: 11) „,neizrecivog i mračnog” у теми угрожености и насиља карневализује немоћ ликова која и настаје кретањима дезоријентисаних особина помјерености. Док библијски Јов каже: „Šta je čovjek da ga mnogo cijeniš i mariš za nj?” (Булатовић 1989a: 5), Булатовићев приповједач умножава и карневализује дифузни свијет трагикомичних „лакрдијаша” и „луда”. Ако је, како каже Бахтин, „karneval drugi život naroda, organizovan na principu smeha" (Бахтин 1978: 15), онда се смисао Булатовићеве карневализације тиче „viših ciljeva čovekovog postojanja”, односно „sveta ideala”, без којих, закључује Бахтин, „nema i ne može biti nikakve prazničnosti” (Исто: 15). Услов за празничност у Булатовићевим приповјеткама испуњен је покушајима јунака за прекорачењем властите ограничености. Сликар Милан тежи да „nadvisi sve ljude” (Булатовић 1989а: 145) и да наслика смрт, Палишума да открије најдубље стање патње и да се ожени, Ева да роди... Интегритет „događaja bez reda” и логичког поретка, с дескрипцијом „pijanica”, „slobodnih mislilaca”, ,podzemnih genija”, „šizofrenika”, „ljudi od mraka”, „od pene i senke”, „nebotičnika”, ликова с „temeljima od ljudskih patnji i gline”, „dremovnih telesa”, у простору гробља, кафана, поткровља, докова, учинио је да се Булатовићев свијет не обликује питањем о смислу, већ питањем о крајњим границама пада који карневализују ликови без поријекла и традиције, без индивидуалности, осим оне која нуди антропоморфну везу ликова и инсеката; ликова и гротескних маски.

Карневалски аспект празничности у књизи Вук $u$ звоно подразумијева преиначење или обарање ,vladajućeg pogleda na svijet” (Бахтин 1978: 28). По- 
тенцијал приповједне инверзије тиче се ратне теме. Њом Булатовић даје још један „орštenarodni organizam” (Бахтин 1978: 58) ликова, сачињен од ватре и пожара, од ликова у стањима подијељености и деоба, заробљености и заточења у пороку, гријеху, злочину, љубави и прижељкивању добра. Ликови су одијељени мјестом радње, ознакама на капама, обручом ватре и људске несреће која им обострано припада, споља и изнутра, на друму или у тамници, лудници, у души или успоменама. На тај начин, једно се садржи у другом, као што се тема „роvučenih, začaurenih i otuđenih ljudi” садржи у животу приче (,vatra rađa nas ljude, naše priče i sudbine...”). Смрт рађа живот, каже Бахтин, а гротеска Булатовићевих ликова - ,probisveta”, „dronjavih skitača”, ,ljudi od svetlosti” и „ljubavi”, карневалски дух необичних збивања, тајновитих и скривених прича о страху, страдању и озарењу. Тако се, из приче у причу, гради простор за „,svaku individualnost izvan veze s poslednjom celinom, za koju je već bila izgubljena stara slika i još nije nađena nova" (Бахтин 1978: 63). Измјенама приповједачких перспектива (тачака гледишта), динамизује се и убрзава ритам приповиједања, дескрипција и семантика „zatočenja”, „tavorenja” и „borenja”. Живот ликова има дијаболичне размјере страдања и жртвовања, етички девастиране вриједности кајања и праштања. Судбине хоџа, попова, црквењака, звонара, деце, отпадника, „nikogovića i kućića”, „nesrećnika”, и других ликова, садрже свијест о кривици и избављењу. Аутор, тим начином, усредсређује читаоца на контрапункт људског пораза, на поступак снижавања којим из дубине зла говори о свјетлости и божанској хармонији. Булатовићеви јунаци из свијета зла теже добру. Рат као епска тема декомпонује се преласком с историјски важне на егзистенцијално маркантне мотиве атипичних ситуација и стања јунака. Карневализација земаљске осуђености на патњу, с просторима „iznad” и „ispod vatre”, с виђењима ликова „odozgo” и с мјеста радње (по „sokačićima, malim i tesnim kućama, podrumima i tavanima”, „oko seoskih plotova”, „malih i neuglednih grobalja”, ,zgradurine” у касаби) отворила је тему егзистенције изван „ustaljenog mira i ravnoteže” (Бахтин 1978: 27). Ликови бескућника, живих мртваца, сакатих, кљастих, слијепих, хромих, „blatnjavih” фигура непотпуног идентитета, умножили су гротескни поредак слике свијета. Деформност ликова приближила је људско анималном и обрнуто, због чега, аутор и овдје пореди и поистовјећује особине ликова с особинама животиња, карактеристичних у поређењима младића и гуштера, „starčića” и „svrake”, човјека и паука итд. Гротескна напоредност лијепог и ружног учинила је да се реалност урнебесне збиље приповиједа из средишта душе, из патње коју носе Булатовићеви јунаци. Више појединачних прича: о дјечаку и јарету, повратнику и старици, вуку и звону, нпр., упућују на поетску симболизацију егзистенције, на њено трајање и истину једне повијести (,povesti o ognju, zatočenicima i još nekim ljudima”), којој се, у обједињености страдања и отуђења, чита библијска тема осуђености на патњу: „Samo želimo da saznamo ko je nesrećniji” (Булатовић 1989б: 11). Мотиви рата, таквим избором, пребацују фокус приповиједања на тему „надражујуће празнине” (Булатовић 1989б: 46) и сасвим иреалне визије спасења. Приповијетке о рату, на тај начин, носе два пола човјековог искуства - голготу зла и сасвим лирско 
самоосјећање небеског, сунчевог, божанског одређења. Тема порока и страсти карневализује посувраћену перспективу ружног и лијепог.

Поступак карневализације присутан је и у књизи Црвени петао лети према небу. Он се огледа у поетској инверзији патријархалне средине, у декомпозицији њене традиције, у инверзији породичног живота и традиционалних мотива свадбе и сахране. Младић Мухарем спушта се у село да прода пијетла и постане човјек, али га људи, насиљем зла у себи, покоравају - и Мухарем губи човечност у некрофиличном искуству на гробљу. Хронотоп пута захвата простор завичаја и патријархалне традиције, као што простор свадбе и сахране захвата контрапункт постојања у хаосу, у паду или немогућности спасења. Луда Мара, Мухарем, старац Илија, Иванка, Кајица - исказују амбивалентни простор сна и јаве, гротескно и фантастично одређен збивањима без херојско-патриотског насљеђа. Луда Мара је резонер изгубљене чистоте и насиља, а карневализована структура свадбара, гробара, луталица, чланова патријархалне породице резултат „karnevalskog svetogrđa”, схватљив у ослобађању и деканонизацији етичких вриједности „оd vladajuće istine i postojećeg poretka”, од „svih hijerarhijskih odnosa, privilegija, normi i zabrana” (Бахтин 1978: 16). Друштвена и социјална позиција јунака „маскира” узроке пада под дејством дисхармоничних збивања.

Тема патријархалне породице, као доминанта, губи идилични ореол и добија онеобичену первертираност патријархалних вриједности. Митске слике свадбе (живота) и сахране (смрти) гротескно осцилирају: гротеска снижава људску недовољност, а пародија је уздиже. Изобличеност егзистенције израста из патријархално-фолклорне структуре црногорског друштва, али и из трагикомичне дезорјентације и изгубљености. На дјелу је карневализација страха, немира и усамљености, мрачних агона и насиља, љубави, помјерености и лудила. Дијаболичност и девастација патријархалних вриједности изневјерава конвенције реалистичког приповиједања. Ексцесни догађаји, стања пада и симболичног узлета сурвали су се у „pregrejani urnebes" двадесет и осам прича - поглавља о старцу Илији и ванбрачном сину Мухарему, синовцу Кајици и невјести Иванки, снахи Анђелији и Ниџари, лудој Мари, гробарима Срећку и Исмету и луталицама Петру и Јовану. Мотиви порока и страсти, у бајковитом спектру људског ужаса, установљују и релативизују однос „,ispremetane” и „іscjepkane priče” (Ласић 1977: 57), а Булатовићев начин „прослављања” гротескних изобличења, оксиморонске правце створеног свијета који сигнализира мисао о добру, о „реtlu” и црвеној боји љубави и снаге, са и без политичке импликације у теми комунизма и у алегоријској структури идеолошког насиља и тортуре. Петао је и „žar-ptica”, симбол добра, семантичко одредиште душе и срца, које, сасвим апсурдно, губи и сам Мухарем, невини лик Булатовићевог театра апсурда. Да карневализација нуди другачију слику од оне с којом Мухарем улази у причу говори трансформација лика на њеном крају. И он добија демонска обиљежја, и он некрофиличним искуством губи човјечност којој је тежио. И Мухарем је „ђаво” Булатовићеве прозе, лик актант амбивалентне реалности егзистенције. Разградња ликова омогућава „органску снагу живог приповиједања” 
(Ејхенбаум 1970: 243), а двосмисленост приказаног свијета, симболично остварену стварност зла.

У вертикали светог и профаног, у деконструкцији патње, с фасцинантношћу њене појаве, Булатовић карневализује свијет „bezazlenih automata što se kreću, voštanih figura, pa i ljudskih marioneta" (Тамарин 1962: 21). Карневализација ликова у свакој лирски изговореној нади, емоцији, озарењу и хиперболичним особинама инфантилности, пијанства, изглобљености, карактерише контраст с устаљеним редом ствари. У простору паганске и хришћанске традиције, у митском ритуалу рађања и нестајања, карневалски дух Булатовићеве прозе садржи узвишеност измаштаног свијета којим аутор лирски исповиједа сан о срећи. Он се, сасвим апсурдно, руши и у драми Годо је дошао. Гротеска „с̌ovečanstva koje iščekuje jednog jedinog čoveka... da nas uteši i spase" преводи озбиљност теме у игру с апсурдом, а неизвјесност спасења у поетски поливалентан вид комедије, фарсе, повијести, сатире, игре. Свијет драме је, као и у приповијеткама, саграђен од снижавања предметности и идеје да „свет није онакав каквим га је направио (или затекао, нашао и оставио Бекет), већ да је „много гори”. Булатовић сматра да није довољно „подсмевати му се”, већ га треба разорити. Он то и чини, карневализацијом симбола људске несреће. Инверзија Бога и пекара, учинила је да се тема врховног духовног принципа замијени улогом пекара, смијешног и бијелог, обликованог снижавањем „озбиљне приче”. Булатовићев Годо је „пекар међу жапцима и кловновима” (Булатовић 1994: 111), лик из народа, дио циркуса. Умјесто месије и спаситеља долази пекар (,Жао ми је што су се разочарали. Очекивали свеца, а дочекали пекара” (Исто: 113), човјек „лудости” („како је дивно што лудости нема краја”). У драми, сасвим у духу карневалске слике постојања, Булатовић преиначава Бекетову поетску „формулу” спасења. Булатовић вјерује да није „све у хлебу и љубави” (Исто: 152), да није све ни у слободи, већ у сазнању да је она немогућа („Омча мора бити око нечијег врата. Слобода не постоји сем у књигама" (Исто: 154). Булатовићев Годо уништава илузију добра и он се из спектра наде опрашта од „тужне” и „смешне” идеје испуњења. Дјечак тјера Годоа: „Одлази... ти си ђаво!” (Исто: 181), вјерујући у испуњење наде: „Sve što je bilo kultno i ograničeno ovde je otpalo, ali je ostalo ono sveljudsko, univerzalno, i utopijsko" (Бахтин 1978: 19). Поступак карневализације, на тај начин, и овдје, у драми, говори о естетски дјелотворној имагинацији која „празнује” гротескне и фантастичне облике угрожене егзистенције и њихову поетску несводивост у односу на мисао да се свијет зла, на тај начин, интензивира у сазнању изгубљеног добра. 


\section{ЛИТЕРАТУРА}

Бартош 1965: О. Бартош, Биљешке уз теорију и типологију гротеске, у: Умjетност ријечи, Загреб, 1965.

Бахтин 1967: M. Bahtin, Problemi poetike Dostojevskog, Beograd: Nolit.

Бахтин 1978: M. Bahtin, Stvaralaštvo Fransoa Rablea i narodna kultura srednjeg veka i renesanse, Beograd: Nolit.

Булатовић 1989a: M. Bulatović, Đavoli dolaze, Sabrana dela Miodraga Bulatovića, knj. 1, Beograd: Prosveta.

Булатовић 1989б: M. Bulatović, Vuk i zvono: povesti o ognju, zatočenicima i još nekim ljudima, knj. 2, Sabrana dela Miodraga Bulatovića, Beograd: Prosveta.

Булатовић 1989в: M. Bulatović, Crveni petao leti prema nebu, Sabrana dela Miodraga Bulatovića,knj. 3, Beograd: Prosveta.

Булатовић 1994: Годо је дошао и друге драме, Београд: Студио дизајн.

Ејхенбаум 1970: Б. Ејхенбаум, Како је направљен Гогољев Шињел, у: Поетика руског формализма, Београд: Просвета.

Кајзер 1995: В. Кајзер, Покушај одређења суштине гротескног, Реч: часопис за книжевност и културу, год. 2, бр. 10.

Ласић 1977: S. Lasić, Problemi narativne strukture: prilog topologiji narativne sintagmatike, Zagreb: Liber.

Тамарин 1962: G. R. Tamarin, Teorija groteske, Sarajevo: Svjetlost.

Lidija R. Tomić

PROCESSES OF CARNIVALIZATION IN THE SHORT STORIES OF MIODRAG

BULATOVIĆ

(Summary)

The work under this title examines the process of carnivalization related to the short stories of Miodrag Bulatović. The paper refers to the part of the narrative with the intention to study the signs and signals of Bulatović's narrative method. The opening thesis reveals the setting of Bulatović's gorgeous world of grotesque and fantastic imagery structures of the world, where by parody and irony themes of evil are poetically and lyrically linked to the theme of good. The work does not introduce the exciting space of Bulatović's pictures of the world, but penetrates the aspects of the play Godot Has Come with the idea of the saviour. If the process of carnivalization is in the function of poetic freedom which aims at achieving the fullness of life and freedom of imagination within the darkness of precipice and nothingness, then we have brought a different vision of the savior into the relationship with a hero who is not one. Bulatović's Godot is just one of the "devils" that the author uses to challenge the sense of existence. 